\title{
Financial Modelling of Feed-In Tariff for Increasing Solar Photovoltaic Energy Portfolio in Malawi
}

\author{
Isaac Chitedze ${ }^{1, ~ *, ~ N w e d e h ~ C h u k w u e m e k a ~ C o s m a s ~}{ }^{2}$, Cohen Ang' ${ }^{3}$ \\ ${ }^{1}$ Faculty of Science, Technology and Innovations, Department of Energy Systems, Mzuzu University, Mzuzu, Malawi \\ ${ }^{2}$ Centre for Petroleum, Energy Economics and Law, University of Ibadan, Ibadan, Nigeria \\ ${ }^{3}$ Wangari Mathai Institute for Peace and Environmental Studies, University of Nairobi, Nairobi, Kenya \\ Email address: \\ chitedze.i@mzuni.ac.mw (I. Chitedze),cosmasnwedeh@gmail.com (N. C. Cosmas), cangu@uonbi.ac.ke (C. Ang’u) \\ ${ }^{*}$ Corresponding author
}

\section{To cite this article:}

Isaac Chitedze, Nwedeh Chukwuemeka Cosmas, Cohen Ang'u. Financial Modelling of Feed-In Tariff for Increasing Solar Photovoltaic Energy Portfolio in Malawi. Journal of Energy and Natural Resources. Vol. 9, No. 1, 2020, pp. 14-27. doi: 10.11648/j.jenr.20200901.13

Received: January 9, 2020; Accepted: February 4, 2020; Published: February 14, 2020

\begin{abstract}
The Feed-In Tariff (FIT) policy has contributed significantly in driving renewable energy investment around the world. Despite the lessons of FIT's contribution in attracting private investment in renewable energy development around the world, Malawi's FIT policy of 2012 has not attracted any private investor. This paper examined the financial modelling of feed-in tariff rates, using Kamazu International Airport solar farm in Malawi as a case study. The paper also analysed the major challenges encountered in implementing the FIT policy in Malawi and funding options for the policy. This paper presents policymakers and planners an analysis on why FIT policy in Malawi has not increased renewable electricity generation capacity. The paper outlines a financial modelling of the FIT using RETScreen Expert. The analysis shows that the FIT for solar in Malawi is significantly lower than a minimum rate that would make a solar PV investment financially viable. The Malawi FIT policy stipulate US $\$ 0.10$ and US $\$ 0.20$ for non-firm power (without storage) and firm power (with storage) respectively. The results of the financial modelling presented herein show that for a ten years payback period; the minimum FIT required is US $\$ 0.34$ with an annual escalation rate of $5 \%$. It is also shown that at US\$0.22, to achieve a payback period of 10 years; an annual escalation rate of $10 \%$ would be required. Given the financial modelling results, the Solar Photovoltaic (PV) FIT in Malawi requires review for enhancement of solar investment in the country.
\end{abstract}

Keywords: Financial Modelling, Feed-in Tariff, RETSCreen, Solar PV

\section{Introduction}

Feed-In Tariff (FIT) is a financial policy scheme or mechanism paid to renewable energy generators that makes provision for generated electricity to be fed into the national grid at a regulated price. It encourages investment in renewable energy (RE) projects by providing a guarantee to long-term availability and access to electricity market to Independent Power Producers (IPP) to sell their generated power into the grid [1, 2]. FIT Policy fixes the wholesale price for the purchase of electricity generated from the renewable source, normally paying generators a premium rate over the retail electricity price for each unit of electricity fed into the grid [3]. The Feed-In Tariff policies have increased investment in energy generation from renewable sources [4]. For instance, Feed-In Tariff policies have promoted the growth of solar photovoltaic installations in Europe, including Germany, Spain, and France [5]. In Europe alone, FIT policy accounted for $93 \%$ of all onshore wind capacity and entirely $100 \%$ of solar photovoltaics installed by the end of 2010 [6]. FIT enabled the UK to reach installation of $2000 \mathrm{MW}$ in 2013, after three years when FIT was introduced in 2010 [7]. The FIT is described as a "true revolutionary tool" in the power sector accounting for the greatest deployment of renewable energy more than all other existing renewable energy policy instruments [2, 8, 9]. However, variations in economic conditions at local levels exacerbate the complexity of wholesale adoption and application of FITs developed for different economic environments.

The Policy Action on Climate Toolkit (PACT) describes 
FIT as a policy that serves dualistic purposes, including access and price objectives. Firstly, the access objective entails the utility company that generates electricity and the grid to grant parallel grid connections and wholesale electricity prices [10]. This assures investors in renewable energy that they can sell all the power they produce, and in case of a temporal excess supply, the renewable power is not turned off. Instead, conventional power plants have to be stopped resulting in a process that may not be cost effective for certain technologies [11]. The price objective establishes a reasonable price, offering a guarantee on price for a fixed period of time, and earns fair returns on investment. The system focuses on price or tariff, wholesale period, wholesale rate, and tariff digression [12].

FIT payment calculation methodology is one of the elements fundamentally designed to guide the policymakers in deciding the price for the electricity generated by the IPPs. There are four different approaches or methodologies used worldwide in designing and calculating price to determine the FIT payment levels. Firstly, the payment design is based on the actual levelized cost of generated renewable electricity, plus estimated profit, which the policymakers or regulators usually decide. This approach is the most commonly used in the European Union (EU) and has been the most successful FIT policy option in driving rapid RE deployment. The second is based on the value of the RE generated either to society or to the utility, typically expressed in terms of "avoided costs." The value to the society accounts for the attributes of the electricity plus sustainability and climate change mitigation, health and safety impacts, energy security, supply diversity and other external costs or externalities. This approach is commonly used in the United States like in California, in addition to British Columbia but in the United States, it has experienced more limited success. [1, 13, 14].

A third approach largely used by some utilities in the United States offers the FIT payment as a fixed-price incentive without regard to actual levelized RE generation costs or avoided costs. In this approach, a fixed-tariff is established arbitrarily as an economic incentive that offers a purchase price for renewable electricity without regard to generation costs or the notion of value to society or utility.
Just like the second approach, this design option has also experienced limited success in the United States [14]. The fourth and last approach on FIT price calculation methodology is the auction-based mechanisms. Both China and India have tried out this approach as the bidding process to help in discovering the actual tariff or price that is appealing to the market $[1,15]$.

Financial modeling of FITs can support the generation of strategic information that policymakers may need for the development of FITs that are relevant, realistic and sustainable within the context of local economic conditions. This paper provides a decision support framework for policymakers in the development of FITs. The paper highlights the role financial modeling of FITs can play in the development of realistic FITs using a case study of Kamuzu International Airport (KIA) solar farm in Malawi. The novelty of this research lies in the topic it covers and the tool it uses: it uses RETScreen Expert with six unique policy scenarios to better understand the role of FIT policy in the deployment of renewables in Malawi.

\subsection{The Malawi Feed-in Tariff Policy}

Malawi Energy Regulatory Authority [16] introduced feedin tariffs in 2012 as a policy tool to drive the development of renewable power generation in Malawi. The FIT tool has three objectives, firstly to facilitate renewable energy resource mobilization by providing investment security and market stability for investors in electricity generation from renewable energy sources. The second objective is to reduce transaction and administrative costs and delays by eliminating the conventional bidding processes and lastly to encourage private investors to operate their power plants prudently and efficiently to maximize returns. As a commitment to encourage Independent Power Producers (IPPs) to invest in renewable power generation, the designed feed-in prices tool was based on the cost of various technologies since generation costs vary for different renewable energy technologies as shown in the table below. The policy categorizes six eligible technologies as means of ensuring diversity and security of supply.

Table 1. Malawi Feed-In Tariff rates.

\begin{tabular}{lllll}
\hline Renewable Fuel & Project Size Tranche & Firm Power Tariff $(\boldsymbol{k} / \mathbf{k W h})$ & Non-Firm Power Tariff $(\mathbf{k} / \mathbf{k W h})$ & Duration \\
\hline & $500 \mathrm{~kW}-1 \mathrm{MW}$ & 14.0 & 13.0 & $20 \mathrm{yrs}$ \\
Hydropower & $1-5 \mathrm{MW}$ & 12.0 & 10.0 & $20 \mathrm{yrs}$. \\
& $5-10 \mathrm{MW}$ & 10.0 & 8.0 & $20 \mathrm{yrs}$. \\
Solar & $500 \mathrm{~kW}-10 \mathrm{MW}$ & 20.0 & 10.0 & $20 \mathrm{yrs}$ \\
Biomass & $500 \mathrm{~kW}-100 \mathrm{MW}$ & 10.0 & 8.0 & $20 \mathrm{yrs}$ \\
Biogas & $500 \mathrm{~kW}-50 \mathrm{MW}$ & 10.0 & 8.0 & $20 \mathrm{yrs}$ \\
Wind & $500 \mathrm{~kW}-50 \mathrm{MW}$ & 13.0 & 13.0 & $20 \mathrm{yrs}$ \\
Geothermal & $0-50 \mathrm{MW}$ & 10.5 & 10.5 & $20 \mathrm{yrs}$. \\
\hline
\end{tabular}

Source: MERA, 2012.

Only hydropower has a stepped tariff design as shown in the differentiated prices offered to investors from the same renewable energy source. The condition for solar tariffs is applicable to the first $100 \mathrm{MW}$ firm power (with storage) generating stations whereas the non-firm power (without storage) rate is valid to first $50 \mathrm{MW}$ solar based power plants 
developed in the country [16]. MERA introduced various capacity caps on each eligible technology as a way of controlling market saturation or unprecedented growth of renewable energy and on the other hand, to limit the policy costs as shown in the table below.

Table 2. Malawi FIT policy caps.

\begin{tabular}{lll}
\hline TECHNOLOGY & CAP (MW) & CATEGORY \\
\hline Hydropower & 150 & Firm power (with storage) \\
& 50 & Non-firm power (without storage) \\
Solar & 100 & Firm power (with storage) \\
& 50 & Non-firm power (without storage) \\
Biomass & 200 & Firm power (with storage) \\
& 50 & Non-firm power (without storage) \\
Biogas & 100 & Firm power (with storage) \\
& 50 & Non-firm power (without storage) \\
Wind & 200 & Cumulative \\
Geothermal & 200 & Cumulative \\
Total & 1150 & \\
\hline
\end{tabular}

Source: MERA, 2012.

The grid operator, Electricity Supply Corporation of Malawi (ESCOM), is mandated to connect all renewable power plants, guarantee priority purchase and dispatch. The policy obliges ESCOM to construct or upgrade the grid network necessary to accommodate the interconnection of renewable energy power plants. This also includes construction of new substations.

\subsection{Background of the Case Study Area}

Kamuzu International Airport solar farm was a grant project from the Japanese government which was built in 2013 under Japan International Corporation Agency (JICA) in Malawi. The solar farm investment cost was USD 8.3 million including overhead costs and generate a maximum of $830 \mathrm{~kW}[17,18]$. This is the first ever and only power generation facility with a connection to the Electricity Supply Commission of Malawi (ESCOM) grid. The system consists of 3540 Panasonic solar panels with 200 panels connected in the block. The solar farm has 9 Nissin Electric inverters with each inverter having a rated output capacity of $100 \mathrm{~kW}$ and operating at $95 \%$ efficiency.

The project saw the introduction of clean energy through solar electricity generation system by the Japanese government in support of Malawi government initiatives to increase deployment of renewable energy technologies (RETs). In order to exploit RETs, the Malawi government adopted the feed-in tariff, a supply policy that exists in 110 countries according to Renewables Global Status Report [19, 12]. The Malawi 2012 FIT policy is similar to the Kenyan 2010 FIT policy $[16,20]$. The policy has been unsuccessful due to the tariffs offered to investors that are not cost reflective to boost investor confidence in the Malawi RE sector considering the macroeconomic instability. However, the Kenyan FIT has been successful in attracting investors with various plant capacities such as the Mumias $29 \mathrm{MW}$ Sugar biomass plant, O Power 40 MW geothermal, 0.5 MW hydropower installed by Imenti Tea Factory, KenGen 5 MW geothermal wellhead and Africa's 2.2 MW first gridconnected biogas plant by Tropical Power Kenya [21-24]. Similarly, FIT has increased solar installed capacity in EU region [25] such that FIT accounted for entirely $100 \%$ of solar photovoltaics installed by the end of 2010 [6].

The Malawi feed-in tariff was modelled as no IPP is feeding power into the national grid, under the existing feedin tariff policy. Why the FIT policy has not increased renewable electricity generation capacity in Malawi? The paper presents a systematic analysis of policy implementation challenges. The financial modeling was done to harmonize tariffs offered to investors, as stakeholders advocated for cost reflective tariffs to boost IPPs confidence in the Malawi power sector, considering the macroeconomic risks induced by exchange rate vulnerability, inflation, among other macroeconomic shocks in a fragile Malawian economy. In reaction to this policy, some stakeholders tend to wonder why the airport pay bills to ESCOM, yet it has a solar farm that feeds power into the grid as the $830 \mathrm{~kW}$ is enough for the airport operations, and the surplus electricity is sold to the national grid. The gaps prompted the financial modeling of the solar farm to calculate the level of profitability of feed-in tariff rates. Lack of cost reflective tariff system discourages investors into the power sector as they will neither recover costs nor make profits. To measure this variable, the feed-in tariff calculated was modeled using RETScreen to determine the appropriate level of tariff under six scenarios, so that investors could earn a $10 \%$ Internal Rate of Return. An effective FIT policy has been argued as a superior policy in reducing the financial risk for investors $[26,27]$.

\section{Materials and Methods}

\subsection{Description of the System}

The Kamuzu International Airport (KIA) is located in the Capital City of Malawi at latitude $13.789^{\circ} \mathrm{S}$ and longitude $33.781^{\circ} \mathrm{E}$ at an altitude of $1230 \mathrm{~m}$ above sea level. The KIA solar farm generate a maximum of $830 \mathrm{~kW}$ [17] and the system cost was USD 6.3 million $(75 \%)$ and the overhead cost USD 2 million (25\%) as this was a bilateral aid. The system consists of 3540 Panasonic solar panels with 200 
panels connected in the block. The panels are titled at $19^{\circ} \mathrm{C}$ facing equator. The solar farm has Nissin Electric 9 inverters with each inverter having a rated output capacity of $100 \mathrm{~kW}$ and operating at $95 \%$ efficiency. JICA provided 500 panels and one invertor as spares parts for replacing faulty components.

\subsection{Data Sources and Modelling Tool}

The data was collected from Kamuzu International Airport finance and engineering departments and RETScreen Expert Software was used for FIT modelling. RETScreen Expert Software is an intelligent, comprehensive decision-making model that used to assess the viability and performance of renewable energy, cogeneration and energy efficiency projects. This Clean Energy Management Software can also create a Virtual Energy Analyser, a Smart Project Identifier, Financial Risk Assessor and project lifecycle Performance Tracker.

\subsection{Modelling Scenarios}

The financial modeling of Kamuzu Solar farm was done using RETScreen Expert under six policy scenarios which would allow investors to a $10 \%$ Internal Rate of Return (IRR) on equity. The test scenarios used in the model were as follow:

a) Is it a profitable investment if it is not a grant project?

b) How high does FIT need to be to attract investment or turn the project to be viable? c) How high does FIT need to be if tariff of $\$ 0.20 / \mathrm{kWh}$ is escalated at $5 \%$ annually?

d) How high does FIT need to be to attract investment if debt financing was $50 \%$ and equity financing was $50 \%$ ?

e) How high does FIT need to be to attract investment if soft loans are provided?

f) How high does FIT need to be to attract Malawian investment (local investors) if 10\% capital incentive, $50 \%$ equity financing, $40 \%$ debt financing and electricity escalation of $5 \%$ annually are provided?

Kamuzu International airport site information used in RETScreen Expert for financial modeling is presented in Table 3 .

Table 3. Site information for Kamuzu International airport used for financial modeling.

\begin{tabular}{ll}
\hline Parameter & Magnitude \\
\hline System capacity & $830 \mathrm{~kW}$ \\
Tilt angle & $19^{\circ}$ \\
Total system cost & USD 6.3 million \\
Operation \& maintenance cost per year & USD 1440 \\
Inflation rate for operation \& maintenance & $10 \%$ \\
Project life & 20 years \\
Feed-In Tariff & USD $0.20 / \mathrm{kWh}$ \\
Inverter replacement life & 12 years \\
No debt financing & \\
\hline
\end{tabular}

\section{Results and Discussion}

a) Is it a profitable investment if it is not a grant project?

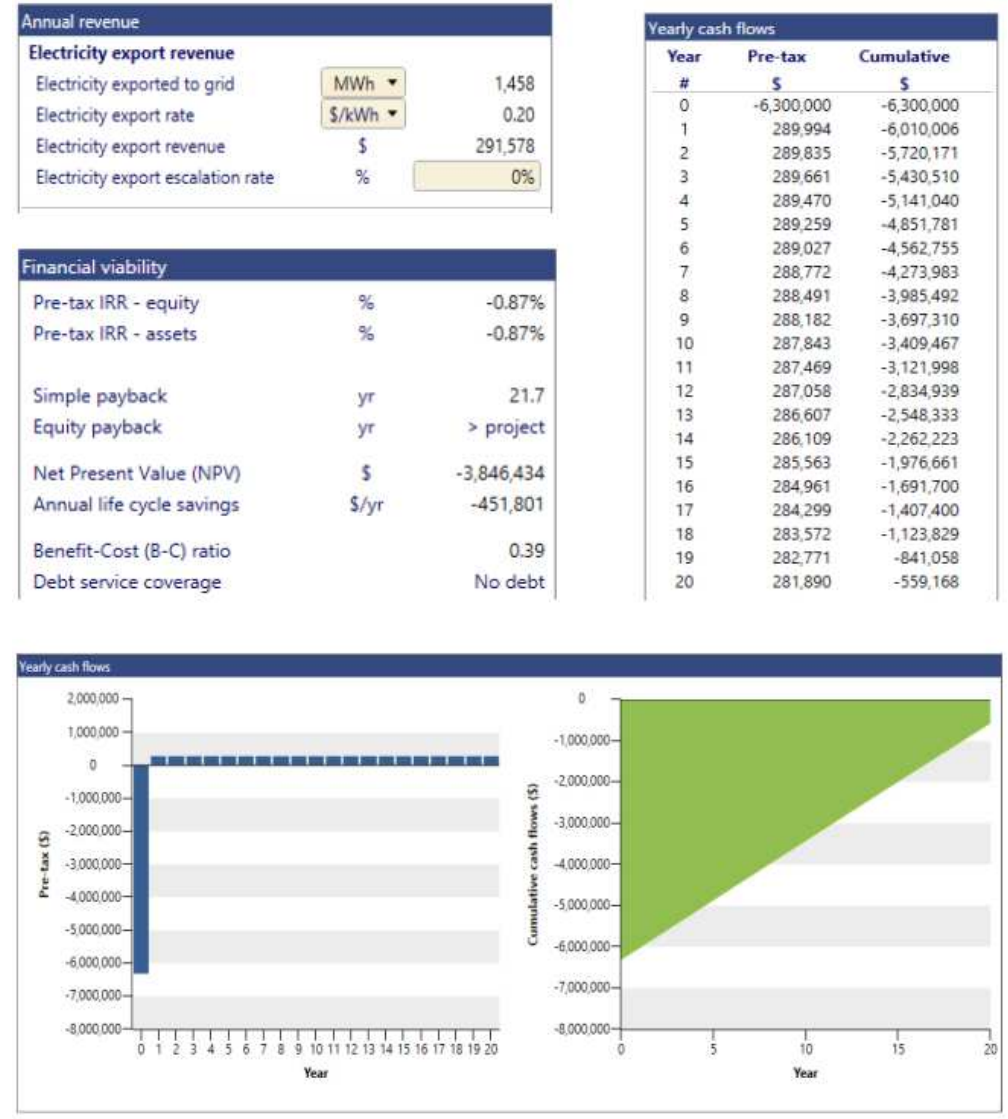

Figure 1. RETSceen results for scenario (a). 
The solar farm project is not profitable as cumulative cash flow never goes past zero and IRR on equity is $-0.87 \%$. From the result, simple payback period is beyond project life. The graph is linear because electricity is not escalating and FIT rate is fixed. In a nutshell, this is not an attractive investment for IPPs.

b) How high does FIT need to be to attract investment or turn the project to be viable?

\begin{tabular}{|c|c|c|}
\hline \multicolumn{3}{|l|}{ Annual revenue } \\
\hline \multicolumn{3}{|l|}{ Electricity export revenue } \\
\hline Electricity exported to grid & $\mathrm{MWh} \cdot$ & 1,458 \\
\hline Electricity export rate & $\$ / \mathrm{kWh} \cdot$ & 0.51 \\
\hline Electricity export revenue & 5 & 743,349 \\
\hline Electricity export escalation rate & $\%$ & $0 \%$ \\
\hline
\end{tabular}

\begin{tabular}{l} 
Financial viability \\
\hline Pre-tax IRR - equity \\
Pre-tax IRR - assets \\
After-tax IRR - equity \\
After-tax IRR - assets \\
Simple payback \\
Equity payback \\
Net Present Value (NPV) \\
Annual life cycle savings \\
Benefit-Cost (B-C) ratio
\end{tabular}

$\begin{array}{rr}\% & 10.0 \% \\ \% & 10.0 \% \\ \% & 10.0 \% \\ \% & 10.0 \% \\ y r & 8.5 \\ y r & 0 \\ \text { S } & 0 \\ \text { yr } & 1.00\end{array}$

\begin{tabular}{|ccc|}
\hline Yearly cash flows \\
\hline Year & Pre-tax & Cumulative \\
$\#$ & \multicolumn{1}{c|}{$\mathbf{S}$} & \multicolumn{1}{c|}{$\mathbf{S}$} \\
\hline 0 & $-6,300,000$ & $-6,300,000$ \\
1 & 741,765 & $-5,558,235$ \\
2 & 741,607 & $-4,816,628$ \\
3 & 741,433 & $-4,075,195$ \\
4 & 741,241 & $-3,333,954$ \\
5 & 741,030 & $-2,592,923$ \\
6 & 740,798 & $-1,852,125$ \\
7 & 740,543 & $-1,111,582$ \\
8 & 740,263 & $-371,319$ \\
9 & 739,954 & 368,635 \\
10 & 739,614 & $1,108,249$ \\
11 & 739,241 & $1,847,490$ \\
12 & 738,830 & $2,586,320$ \\
13 & 738,378 & $3,324,698$ \\
14 & 737,881 & $4,062,579$ \\
15 & 737,334 & $4,799,914$ \\
16 & 736,733 & $5,536,646$ \\
17 & 736,071 & $6,272,717$ \\
18 & 735,343 & $7,008,060$ \\
19 & 734,543 & $7,742,603$ \\
20 & 733,662 & $8,476,265$ \\
& & \\
\hline
\end{tabular}

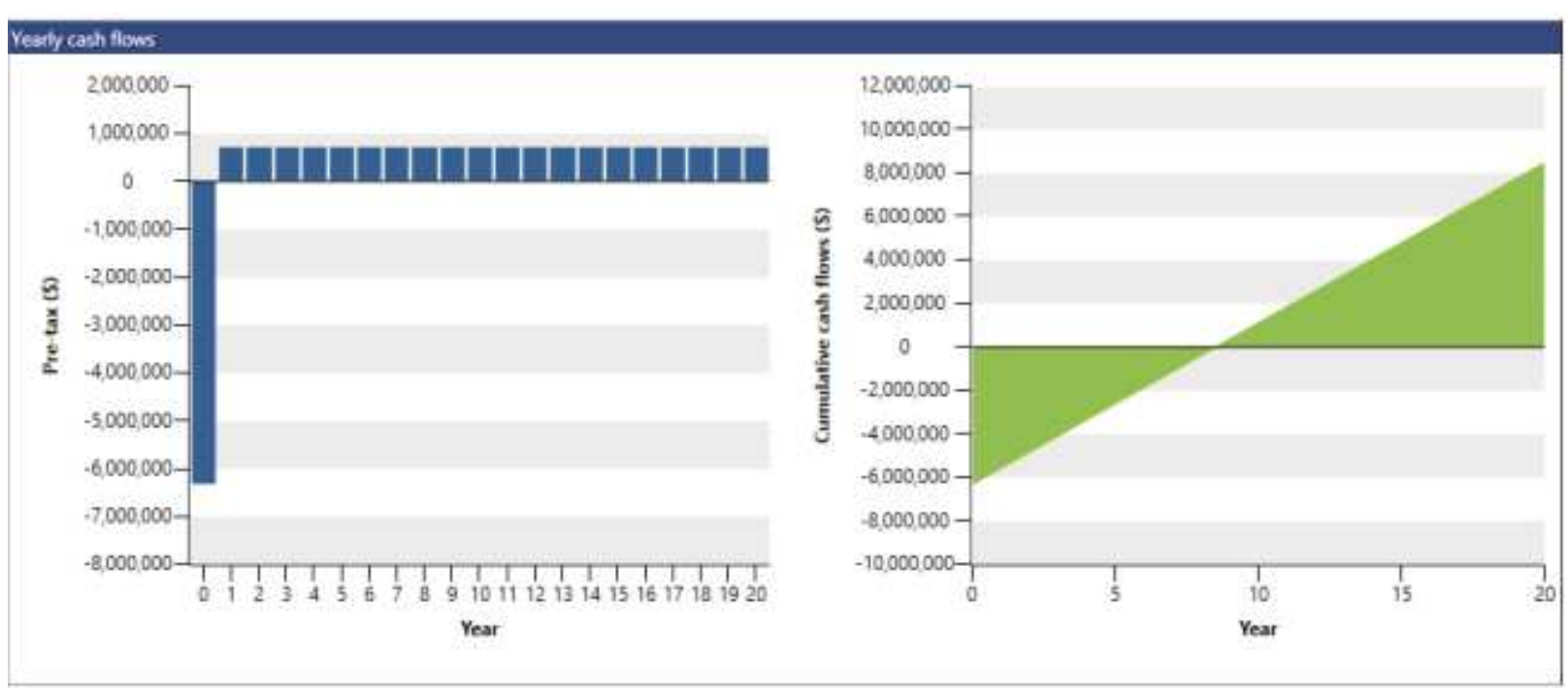

Figure 2. RETSceen results for scenario (b).

To turn the project to profitability, the FIT has to be $\$ 0.51$ KWh to enable investors earn a $10 \%$ IRR on equity. The equity payback period and simple payback period of the project at $\$ 0.51 \mathrm{kWh}$ rate for nine years will certainly attract IPPs. Specifically, at a discount rate of $10 \%$ similar to IRR on equity at $10 \%$, the Net Present Value (NPV) is zero. From the result, the cost benefit ratio of 1 indicates the profitability of the project. From observation, the $\$ 0.51 \mathrm{kWh}$ is high because of the overhead costs, considering the public nature of the solar project and its bilateral aid.

c) How high does FIT need to be if tariff of $\$ 0.20 / \mathrm{kWh}$ is escalated at $5 \%$ annually? 


\begin{tabular}{|c|c|c|}
\hline \multicolumn{3}{|l|}{ Annual revenue } \\
\hline \multicolumn{3}{|l|}{ Electricity export revenue } \\
\hline Electricity exported to grid & $\mathrm{MWh} \cdot$ & 1,458 \\
\hline Electricity export rate & $\$ / \mathrm{kWh} \cdot$ & 0.34 \\
\hline Electricity export revenue & s & 497,645 \\
\hline Electricity export escalation rate & $\%$ & $5 \%$ \\
\hline
\end{tabular}

\begin{tabular}{|lcr|}
\hline Financial viability & & \\
\hline Pre-tax IRR - equity & $\%$ & $10.0 \%$ \\
Pre-tax IRR - assets & $\%$ & $10.0 \%$ \\
After-tax IRR - equity & $\%$ & $10.0 \%$ \\
After-tax IRR - assets & $\%$ & $10.0 \%$ \\
& & \\
Simple payback & yr & 12.7 \\
Equity payback & yr & 9.7 \\
Net Present Value (NPV) & $\$$ & 0 \\
Annual life cycle savings & $\$ / y r$ & 0 \\
Benefit-Cost (B-C) ratio & & 1.00
\end{tabular}

\begin{tabular}{|ccc|}
\hline Yearly cash flows \\
\hline Year & Pre-tax & Cumulative \\
\hline$\#$ & \multicolumn{1}{c|}{$\mathbf{S}$} & \multicolumn{1}{c|}{$\mathbf{S}$} \\
\hline 0 & $-6,300,000$ & $-6,300,000$ \\
1 & 520,943 & $-5,779,057$ \\
2 & 546,911 & $-5,232,146$ \\
3 & 574,170 & $-4,657,976$ \\
4 & 602,782 & $-4,055,194$ \\
5 & 632,816 & $-3,422,378$ \\
6 & 664,341 & $-2,758,037$ \\
7 & 697,430 & $-2,060,606$ \\
8 & 732,162 & $-1,328,445$ \\
9 & 768,615 & $-559,830$ \\
10 & 806,876 & 247,047 \\
11 & 847,033 & $1,094,080$ \\
12 & 889,180 & $1,983,260$ \\
13 & 933,413 & $2,916,672$ \\
14 & 979,835 & $3,896,507$ \\
15 & $1,028,553$ & $4,925,060$ \\
16 & $1,079,680$ & $6,004,740$ \\
17 & $1,133,333$ & $7,138,073$ \\
18 & $1,189,636$ & $8,327,708$ \\
19 & $1,248,717$ & $9,576,426$ \\
20 & $1,310,713$ & $10,887,138$ \\
\hline & & \\
\hline
\end{tabular}

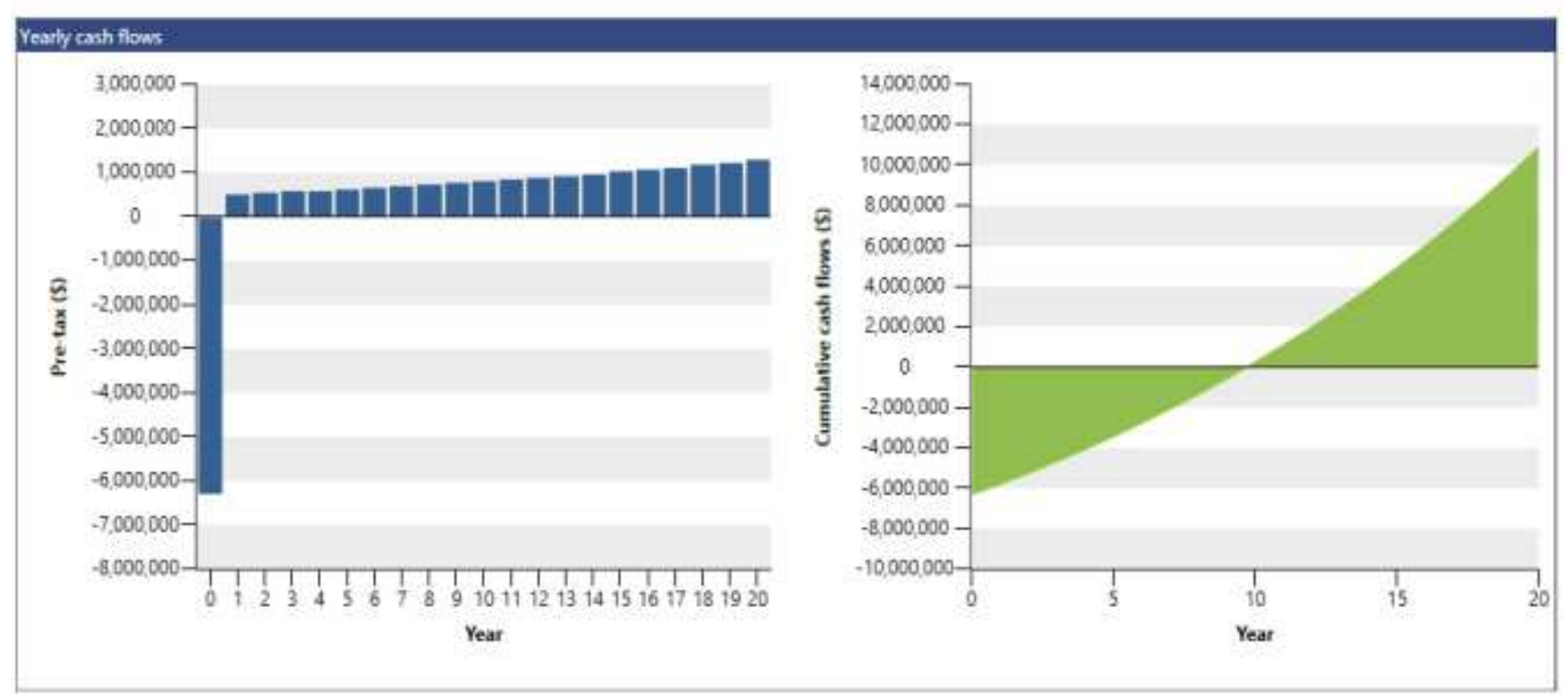

Figure 3. RETSceen results for scenario (c).

Electricity export escalation rate is the projected annual average rate of increase in electricity export rate over the life of the project and it applies the rate of inflation to the value of electricity export rate. At the escalation rate of $5 \%$, which is half of the inflation rate, the FIT rate has to be $\$ 0.34 \mathrm{kWh}$. Since the electricity rate is escalating, the equity payback is ten years while the simple payback period is 13 years. Equity payback represents the length of time it takes for the IPP to recoup its initial investment out of the project cash flows generated. If the electricity escalation rate is $10 \%$ annually from this scenario, FIT rate will be $\$ 0.22 \mathrm{kWh}$.

d) How high does FIT need to be to attract investment if debt financing was $50 \%$ and equity financing was $50 \%$ ? 


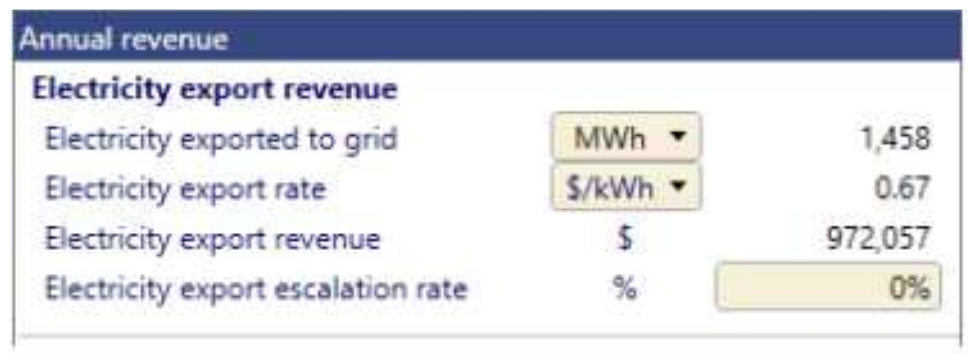

\section{Financial viability}

Pre-tax IRR - equity

Pre-tax $\mathbb{R R}$ - assets

After-tax IRR - equity

After-tax IRR - assets

Simple payback

Equity payback

Net Present Value (NPV)

Annual life cycle savings

Benefit-Cost (B-C) ratio

Debt service coverage

$\begin{array}{cr}\% & 10.0 \% \\ \% & 4.2 \% \\ \% & 10.0 \% \\ \% & 4.2 \% \\ & \\ \text { yr } & 6.5 \\ \text { yr } & 11.8 \\ \text { S } & 0 \\ \text { Slyr } & 0 \\ & 1.00 \\ & 1.17\end{array}$

\begin{tabular}{|ccc|}
\hline Yearly cash flows & \\
\hline Year & Pre-tax & Cumulative \\
$\#$ & \multicolumn{1}{c|}{$\boldsymbol{S}$} & \multicolumn{1}{c|}{$\mathbf{S}$} \\
\hline 0 & $-3,150,000$ & $-3,150,000$ \\
1 & 141,367 & $-3,008,633$ \\
2 & 141,208 & $-2,867,425$ \\
3 & 141,034 & $-2,726,391$ \\
4 & 140,842 & $-2,585,549$ \\
5 & 140,632 & $-2,444,917$ \\
6 & 140,400 & $-2,304,518$ \\
7 & 140,145 & $-2,164,373$ \\
8 & 139,864 & $-2,024,509$ \\
9 & 139,555 & $-1,884,954$ \\
10 & 139,216 & $-1,745,738$ \\
11 & 967,949 & $-777,789$ \\
12 & 967,538 & 189,749 \\
13 & 967,086 & $1,156,835$ \\
14 & 966,589 & $2,123,423$ \\
15 & 966,042 & $3,089,466$ \\
16 & 965,441 & $4,054,906$ \\
17 & 964,779 & $5,019,685$ \\
18 & 964,051 & $5,983,736$ \\
19 & 963,250 & $6,946,986$ \\
20 & 962,370 & $7,909,356$ \\
& & \\
\hline & & \\
\hline 19 & &
\end{tabular}

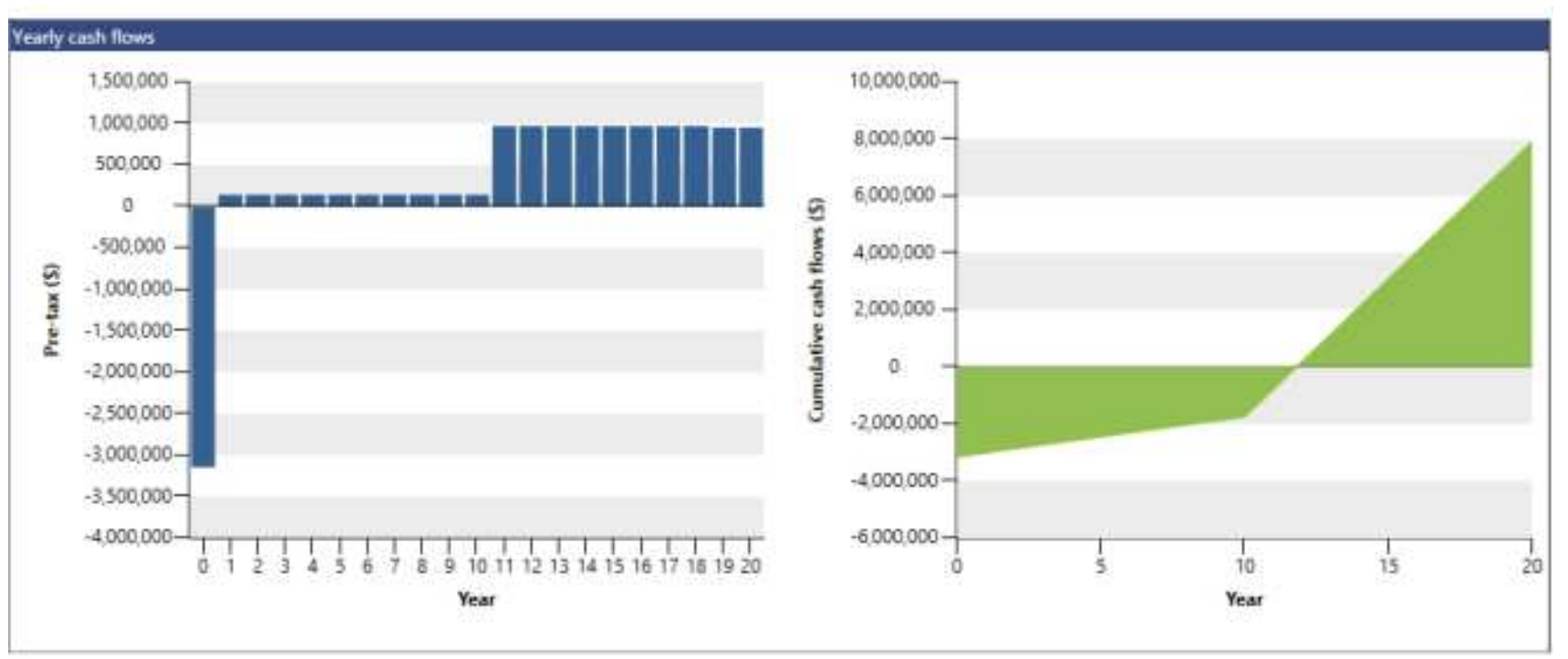

Figure 4. RETSceen results for scenario (d).

The project would need a FIT rate of $\$ 0.67$ if it involves a debt financing of 50\%. The debt interest rate was $23.75 \%$ for commercial banks in 2012, according to statistics from the Reserve Bank of Malawi when the KIA project was being initiated [28]. The simple payback is 7 years whereas the equity payback is 12 years. The simple payback represents the length of time it takes for a proposed project to recoup its own initial cost out of the revenue generated, without taking into account debt repayment. The graph shows export income flow upsurge after 10 years because the debt financing would be repaid.

e) How high does FIT need to be to attract investment if the soft loan was provided? 
The soft loan means a debt interest rate of $13 \%$ used by the Reserve Bank of Malawi instead of $23.75 \%$ charged by commercial banks. If Malawi had implemented that policy option for IPPs, the FIT would have been $\$ 0.54 \mathrm{kWh}$, which would have allowed the IPPs to earn a $10 \%$ IRR on equity.

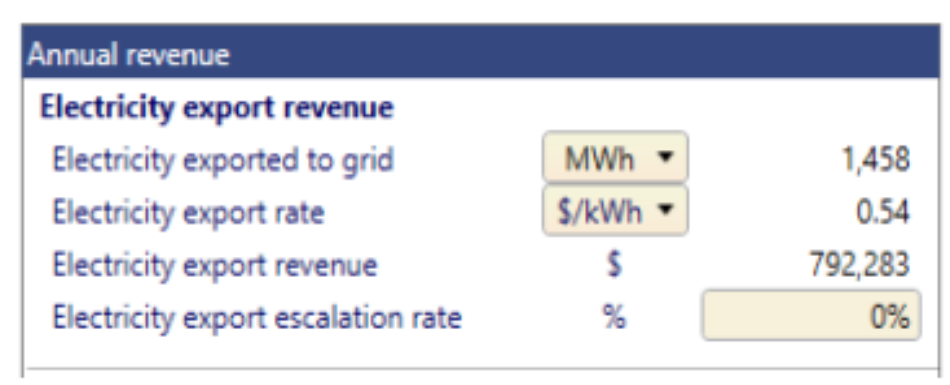

\begin{tabular}{l} 
Financial viability \\
\hline Pre-tax IRR - equity \\
Pre-tax IRR - assets \\
After-tax IRR - equity \\
After-tax IRR - assets \\
Simple payback \\
Equity payback \\
Net Present Value (NPV) \\
Annual life cycle savings \\
Beneftl-Cost (B-C) ratio \\
Debt service coverage
\end{tabular}

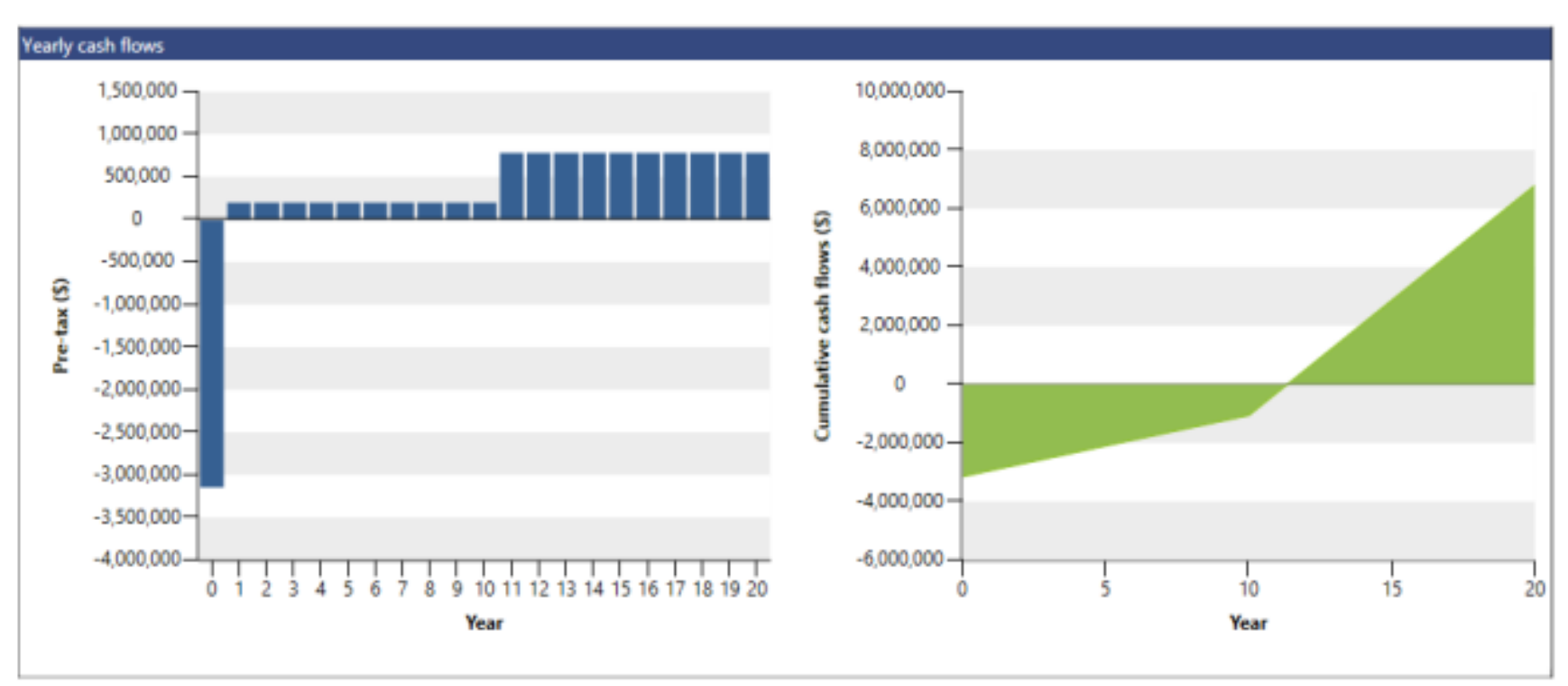

Figure 5. RETSceen results for scenario (e).

\begin{tabular}{|ccc|}
\hline Yearly cash flows & \\
\hline Year & Pre-tax & Cumulative \\
$\#$ & $\$$ & \multicolumn{1}{c|}{$\mathbf{S}$} \\
\hline 0 & $-3,150,000$ & $-3,150,000$ \\
1 & 210,187 & $-2,939,813$ \\
2 & 210,028 & $-2,729,785$ \\
3 & 209,854 & $-2,519,931$ \\
4 & 209,662 & $-2,310,268$ \\
5 & 209,452 & $-2,100,817$ \\
6 & 209,220 & $-1,891,597$ \\
7 & 208,965 & $-1,682,632$ \\
8 & 208,684 & $-1,473,948$ \\
9 & 208,375 & $-1,265,573$ \\
10 & 208,036 & $-1,057,537$ \\
11 & 788,174 & $-269,363$ \\
12 & 787,764 & 518,400 \\
13 & 787,312 & $1,305,712$ \\
14 & 786,814 & $2,092,526$ \\
15 & 786,268 & $2,878,794$ \\
16 & 785,666 & $3,664,460$ \\
17 & 785,004 & $4,449,465$ \\
18 & 784,277 & $5,233,741$ \\
\hline & & \\
\hline
\end{tabular}

f) How high does FIT need to be to attract Malawian investment (local investors) if 10\% capital incentive, 50\% equity financing, $40 \%$ debt financing and electricity escalation of $5 \%$ are provided annually? 


\begin{tabular}{|c|c|c|}
\hline \multicolumn{3}{|l|}{ Annual revenue } \\
\hline \multicolumn{3}{|l|}{ Electricity export revenue } \\
\hline Electricity exported to grid & $\mathrm{MWh} \cdot$ & 1,458 \\
\hline Electricity export rate & $\$ / \mathrm{kWh} \cdot$ & 0.39 \\
\hline Electricity export revenue & s & 570,236 \\
\hline Electricity export escalation rate & $\%$ & $5 \%$ \\
\hline
\end{tabular}

\begin{tabular}{|lcr|}
\hline Financial viability & $\%$ & $10.0 \%$ \\
\hline Pre-tax IRR - equity & $\%$ & $5.7 \%$ \\
Pre-tax IRR - assets & $\%$ & $10.0 \%$ \\
& $\%$ & $5.7 \%$ \\
After-tax IRR - equity & & \\
After-tax IRR - assets & $y r$ & 10.0 \\
Simple payback & $y r$ & 12.3 \\
Equity payback & $\$$ & \\
Net Present Value (NPV) & Siyr & 0 \\
Annual life cycle savings & & 1.00 \\
Benefit-Cost (B-C) ratio & & 0.90 \\
Debt service coverage & &
\end{tabular}

\begin{tabular}{|c|c|c|}
\hline \multicolumn{3}{|c|}{ Yearly cash flows } \\
\hline Year & Pre-tax & Cumulative \\
\hline$\#$ & $\mathbf{s}$ & s \\
\hline 0 & $-3,150,000$ & $-3,150,000$ \\
\hline 1 & $-66,121$ & $-3,216,121$ \\
\hline 2 & $-36,342$ & $-3,252,463$ \\
\hline 3 & $-5,082$ & $-3,257,545$ \\
\hline 4 & 27,732 & $-3,229,813$ \\
\hline 5 & 62,178 & $-3,167,635$ \\
\hline 6 & 98,335 & $-3,069,300$ \\
\hline 7 & 136,288 & $-2,933,012$ \\
\hline 8 & 176,127 & $-2,756,885$ \\
\hline 9 & 217,943 & $-2,538,942$ \\
\hline 10 & 261,835 & $-2,277,107$ \\
\hline 11 & 971,189 & $-1,305,918$ \\
\hline 12 & $1,019,543$ & $-286,374$ \\
\hline 13 & $1,070,295$ & 783,920 \\
\hline 14 & $1,123,561$ & $1,907,481$ \\
\hline 15 & $1,179,465$ & $3,086,946$ \\
\hline 16 & $1,238,138$ & $4,325,084$ \\
\hline 17 & $1,299,714$ & $5,624,798$ \\
\hline 18 & $1,364,336$ & $6,989,134$ \\
\hline 19 & $1,432,152$ & $8,421,286$ \\
\hline 20 & $1,503,319$ & $9,924,605$ \\
\hline
\end{tabular}

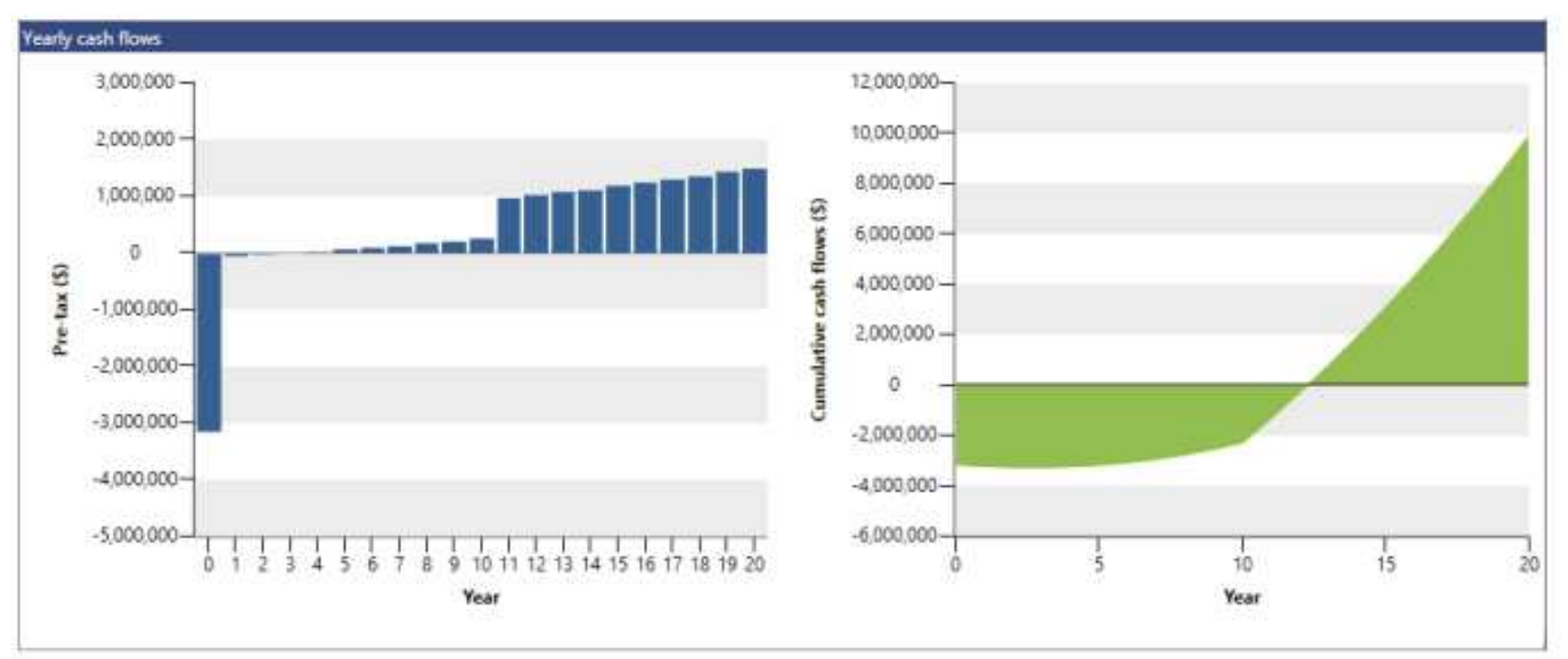

Figure 6. RETSceen results for scenario $(f)$.

The capital incentive is an option to soft loan. If the government cannot provide a soft loan with interest rate equal to the lending rate offered by Reserve Bank of Malawi to commercial banks, then the government can provide capital incentives as a policy option. This capital incentive can encompass rebate, contribution, grant, and subsidy in this scenario, a $10 \%$ contribution or grant on the initial cost of the project to encourage investors to invest in Malawian energy sector. With an escalation rate of 5\% annually, the FIT rate would be $\$ 0.39 \mathrm{kWh}$ with a simple payback of 10 years and equity payback of 12 years. Given the same scenario but with different escalation rate of $10 \%$, the FIT would be $\$ 0.25$ $\mathrm{kWh}$.

\section{FIT Policy Implementation Challenges}

\subsection{Policy Diffusion and Stakeholder Consultation}

The first notable challenge with the Malawi FIT policy is lack of stakeholder consultation in the policy design and development processes. The Malawi 2012 FIT policy is almost a copy-paste of the Kenyan 2010 FIT policy. A critical review of the two policy documents revealed that the 
contents are similar, including the objectives, design criteria and implementation procedures. The Malawi FIT policy differs only in price of one or two cents added to different technologies in comparison to Kenya. This is not a rational policy decision based on the fact that economic growth trajectory of the two nations are largely different. Hence, with such FIT policy objectives and design, investment will be difficult to thrive in the phase of debt finance, interest rate and inflation because of such unconducive investment climate. As a matter of fact, it is important to understand the economics of demand and supply dynamics of nations, before initiating a policy that best works in one nation into another.

For instance, Malawi is a landlocked nation as such landed cost is very high in comparison to Kenya, which owns Mombasa port. Malawi relies on Dares Salaam port in Tanzania or Beira port in Mozambique, which means IPPs will dig deep into their pockets to transport equipment to building a power plant in Malawi. It is not a wonder why Kenya FIT attracted investors within four years while in Malawi, there has not been any IPP feeding power into the national grid. The Malawian FIT policy was designed without reference to national context and prevailing macroeconomic environment. These crucial policy elements were short-sighted during policy design and formulation that have caused serious consequential effects on the FIT policy. The policy development process missed some rationale of good policy decisions in terms of forward-looking, outwardlooking, evidence-based and inclusiveness. Policy development consultation initiative plays key role of ensuring openness and involvement of all stakeholders to analyse and figure out best policy options that achieve public interest [29].

\subsection{Lack of Technical Expertise}

The second challenge encountered is lack of technical expertise in designing tariff rate calculation methodology and drafting the power purchase agreements (PPAs). To address this shortage, in May 2016 the Malawi government in conjunction with Power Africa hired an advisor who was embedded in ESCOM to work directly as part of the utility in facilitating private sector investment in the power sector. The advisor was funded by United States Agency for International Development (USAID) to assist ESCOM in negotiation and drafting Power Purchase Agreement with IPPs [30].

\subsection{Policy Funding}

There is no practical mechanism in place, detailing how to fund the policy cost to ensure policy sustainability or guarantee investors security. The Malawi FIT policy provides ESCOM to recover $70 \%$ of the portion of the FIT from electricity customers on the following technologies: wind, hydropower, biomass, biogas and geothermal. For solar power, the policy grants ESCOM to recover $85 \%$ of the portion of FIT from electricity customers. However, the policy does not stipulate the reclaiming procedure of the remaining $15 \%$ or $30 \%$. Relatively, the rates in the FIT policy are higher than the existing end-user tariff. USAID in its publication on "Malawi Power Africa Fact Sheet" describes the electricity market price as non-cost reflective [30]. This poses a challenge as to how ESCOM will be able to pay for electricity purchased from renewable energy generators. The question remains unanswered: who will fund the gap? This makes generators request for sovereign guarantees from a government, but the latter does not make provision for any. A sovereign guarantee that IPPs request is a promise by the Malawi government to discharge the liability of ESCOM in case of default.

\subsection{Grid Capacity}

Another implementation challenge of Malawi FIT policy is the national grid capacity. A study on the national grid undertaken by Management and Engineering Technologies International (METI) in 2016 revealed that as of 2016, the electricity network infrastructure in Malawi could only accommodate an additional 70 MW maximum evacuation into the grid. The findings from the study disclosed that the maximum solar power plant an IPP could build and connect to the national grid was $17.5 \mathrm{MW}$ as an intermittent renewable source. As such, the southern and central meshed transmission system could connect multiple $17 \mathrm{MW}$ maximum of solar power plants whereas the northern radial transmission network could accommodate a maximum of 15 MW multiple power plants [31]. The Millennium Challenge Account-Malawi in September 2013 began the rehabilitation, upgrading, and modernization of the Malawian electricity network and through the project; Malawi has the first ever $400 \mathrm{kV}$ transmission lines. The Millennium Challenge Corporation and the World Bank's transmission and distribution network upgrade shall provide a secure and reliable transmission network which will accommodate and connect many generators. The transmission network upgrade project is expected to be completed in 2022, but as of 2018, the grid capacity study indicates that up to 300 MW IPPs connections are possible in the electricity network [31].

\subsection{Low Tariff Level}

The last challenge faced in implementing FIT policy is the low tariff level offered to investors as of 2012 when the policy was adopted. Low tariff discourages private investment in the power sector as the projects are deemed unprofitable. In measuring this variable, a Cronbach's Alpha reliability test was carried out in SPSS. Cronbach's Alpha analysis was conducted on the current feed-in tariff rate and it was found that the alpha scale was 0.833 which surpassed the minimum threshold of 0.7 Cronbach's Alpha reliability test. The 0.833 alpha scale indicates that the scale has an adequate level of inter-item reliability. Further analysis revealed that by deleting any item, the alpha level would still be above 0.7. For instance, the Renewables Global Status reports 2017, 2018 and 2019 by REN 21 reveal a decline in prices or rapid falling costs, particularly for solar PV 
modules and onshore wind power. The reports stipulates that the levelised cost of solar energy generation in Africa was between 0.9 to $0.26 \mathrm{USD} / \mathrm{kWh}$ in 2016 while in 2017 it ranged from 0.8 to $0.22 \mathrm{USD} / \mathrm{kWh}$ and between 0.10 to 0.16 USD/kWh in 2018. In 2012 when the FIT was adopted in Malawi, typical solar energy costs ranged between 20-37 US cents/kWh [19, 32, 33, 34]. Malawi as a landlocked nation offer the low economic value to IPPs that are not costreflective. The profitability level and price at which the government set to purchase electricity from IPPs is crucial for the success of FIT schemes. Low tariffs are not appealing to investors hence limited RE deployment, as this conservative remuneration may not be sufficient for renewable energy market expansion [8]. However, high or moderate tariffs tend to attract more investors due to high levels of profitability or returns as this makes less efficient projects financially viable and attractive.

\section{Policy Funding Options}

\subsection{Fuel Levy}

This is one of the viable options as the country has already six fuel levies and one of the levies is dedicated to rural electrification programme [35]. The rural electrification levy is channeled to connecting new customers by expanding the electricity network to different trading centers as a way of increasing electricity access for people in peri-urban and rural areas. The table below shows the fuel levies in Malawi.

Table 4. Malawi Fuel Levies.

\begin{tabular}{llll}
\hline Fuel Levy & Petrol (\$) & Diesel (\$) & Paraffin (\$) \\
\hline Energy regulatory levy & 0.0137 & 0.0137 & 0.0137 \\
Rural electrification levy & 0.0508 & 0.0503 & 0.0401 \\
Price stabilization fund & 0.0309 & 0.0304 & 0.0292 \\
Fuel storage levy & 0.0068 & 0.0068 & 0.0068 \\
Malawi Bureau of Standards (MBS) cess levy & 0.0012 & 0.0012 & 0.0012 \\
Road fund levy & 0.1241 & 0.1229 & - \\
\hline
\end{tabular}

Source: Phiri [35].

With the same generation capacity, there is a need to rethink the rural electrification levy which funds the Malawi Rural Electrification Program (MAREP) so that the fund can partially be channeled to paying IPPs investing in new generation facilities. This is the opposite of the current trend of connecting more trading centers and new customers, yet the generation capacity is still the same. The nation should concentrated on supply-side management to increase the generation capacity with fund from fuel levy, rather than focusing only on the demand-side management. Relatedly, the country can consider introducing a new fuel levy to fund FIT policy which is another possible option. The new fuel levy can generate fund to pay IPPs for their $\mathrm{kWh}$ fed into the national grid.

Alternatively, the MAREP fund can be shared in terms of percentages to pay both IPPs and connecting new customers to the grid. For example, in June 2017, the Ministry of Natural Resources, Energy and Mining announced that MAREP phase 8 would electrify 336 trading centers across the country by the end 2018 to the tune of USD 41 million [36, 37]. According to the Annual Economic Report of 2016, the initial budget was USD 22 million targeting 122 trading centers, but the funding was increased to target many trading centers [38]. Such a huge amount of money can be divided into power generation to funding FIT policy and rural electrification. Likewise, the introduction of electricity levy in price build-up on the electricity bills tariff charged by ESCOM on consumers is another funding option.

For instance, the current market consumption of fuel per day in Malawi is between 1 million and 1.5 million and the retail price of petrol and diesel is USD 1.24 and USD 1.23 respectively [39]. The Rural Electrification Levy cost USD
0.0508 per litre of petrol, 0.0503 per litre of diesel and 0.0401 per litre of paraffin. The Rural Electrification Levy is transferred to the Malawi Rural Electrification Fund that sponsor Malawi Rural Electrification Programme (MAREP). The approach of MAREP is to electrify trading centres or market places in a phased manner. According to Malawi Annual Economic Report for 2018/2019 by the Ministry of Finance, Economic Planning and Development [40] the country imported 209,053,949 litres of petrol, 273,288,620 litres of diesel and 472,207 litres of paraffin. Simply analysis shows that MAREP received USD 10,619,940 from petrol fuel levy, USD 13,746,417 from diesel fuel levy and USD 18,935 from paraffin fuel levy totalling USD 24,385,292. This computation unquestionably, denotes that MAREP gets over USD 24,000,000 annually from fuel levy.

Another source of funds for MAREP is the electricity levy that is charged at $4.5 \%$ at the current average tariff of USD $0.117 / \mathrm{kWh}$ [41]. The electricity purchases forecast billed to customers for 2019/2020 was projected at 2,297,375,853 kWh translating to more than USD 12,000,000 income for MAREP [42]. On the other hand, the Annual Economic Report for 2018/2019 show that the Electricity Supply Corporation of Malawi (ESCOM) sold 1,489,150,000 kWh of electricity to consumers at an average rate of 0.0976/kWh [40]. The income generated for MAREP under this financial year was approximately USD 6,543,000. Taking into account both fuel levy and the electricity levy, the Malawi Rural Electrification Programme collects more than USD 26 million annually for electrify trading centres or market places. These revenues generated from levies justifies the need for the country to concentrate not only on the demand-side but also on supplyside management to increase the generation capacity. 


\subsection{Ratepayer}

Additional means to fund the policy is through ratepayers. This means any added cost should be factored into electricity rate base charged to all power consumers. Adjusting end-user tariffs can ensure that all costs associated with FIT are passed on to the consumers. ESCOM will pay the power producers the wholesale price directly for their power and pass on the costs to electricity consumers in the electricity bills via a surcharge on customer's electricity bills. The existing customer differentiation should be implemented in the ratepayer funding, specifically, domestic customers, general customers, the low voltage supply for industrial users, medium voltage supply for industrial users, etc. the ratepayer should not be an equivalent distribution [1]

\subsection{Electronic Fiscal Device (EFD) Machine}

Maximizing EFD tax collection is a practical way of sourcing funds for the nation and the FIT policy. It is important to note here that most businesses across the country do not have Electronic Fiscal Device (EFD) machine or have them but do not print receipts for goods purchased. To finance FIT, the government should emphasize revenue collection so that businesses remit tax especially Value Added Tax (VAT) and use the revenues prudently for economic development, including investment in electricity generation. Maximizing revenue collection will pave way to financing different programmes such as FIT policy cost. Ethiopia is a good example to emulate because the Ethiopian government intensified prudent use of EFDs generated revenue for national development, notably investment in power generation. What is more, the EFD should be mandatory in Malawi in all business areas with stiff punishment for tax evasion to all businesses that dodge net tax by either operating without EFD or non-issuance of tax invoices, despite having the machine. Recently, the Malawi Revenue Authority (MRA) introduced a campaign called "Lisiti Langa Promotion" whereby customers won various prizes for demanding an EFD receipt every time they purchased goods. This was a good initiative even though it has loopholes that some businesses will continue operating without EFDs as there are no punitive measures.

\section{Conclusions}

FIT policies are the most versatile renewable energy supporting instruments, accounting for the worldwide greatest propagation of renewable energy generation more than all other renewable energy policy schemes. Evidences have shown that Feed-In-Tariff (FIT) policies have contributed significantly in driving renewable energy investment. However, despite its impressive contribution in attracting private investment, the development and application of FIT policy framework are not integrated into the national, local, fiscal and socio-economic policies of Malawi. The policy aims to substantially increase the production of renewable electricity by giving investors economic incentives and leveling the playing fields. Malawi is not exception, it adopted the FIT policy in 2012 to attract more players in the power sector to generate electricity in the following eligible technologies: hydropower, solar, biomass, biogas, wind and geothermal. The major challenge with the 2012 FIT policy was the absence of stakeholder consultation in designing the policy. As such, the policy missed some rationale of good policy decisions in terms of forward-looking, outward-looking, evidence-based and inclusiveness. The case study involved modeling FIT rates for Kamuzu International Airport solar farm under six scenarios and policy options using RETScreen Expert. To turn the KIA project to profitability, the FIT has to be $\$ 0.34 \mathrm{kWh}$, which would allow investors to earn a $10 \%$ internal rate of return on equity. Although the financial model has been developed on a case study basis, the approach can be applied in developing nations with similar economic conditions like those in the study area. The funding options have been recommended to boost investors' confidence to invest and maximize profit and in return increase the government revenue generation from the energy sector.

\section{References}

[1] Couture T. D., Kreycik C., Cory K., Williams E., (2010). A Policymaker's Guide to Feed-in Tariff Policy Design. Colorado. USA, National Renewable Energy Laboratory.

[2] Mendonça M, Jacobs D, Sovacool B., (2010). Powering the Green Economy: The Feed-in Tariff Handbook. London, Earthscan.

[3] Klein A, (2008). Feed-in Tariff Designs: Options to Support Electricity Generation from Renewable Energy Sources. Germany, VDM Verlag Dr. Müeller, Saarbrücken.

[4] Poruschia L., Ambreyb C., Smartc J. Revisiting feed-in tariffs in Australia: A review. Renewable and Sustainable Energy Reviews 2018; 82: 260-270.

[5] Deutsche Bank, (2010). Get FiT Program: Global Energy Transfer Feed-in Tariffs for Developing Countries. Germany, Deutsche Bank Group https://www.researchgate.net/publication/323666220_GET_FiT_ Program Global Energy_Transfer_Feedin_Tariffs_for_developing_countries [accessed on 19 May 2019].

[6] Ragwitz M et al., (2012). Recent developments of feed-in systems in the EU - A research paper for the International Feed-In Cooperation. Ministry for the Environment, Nature Conservation and Nuclear Safety (BMU).

[7] Nolden C., (2015). Performance and Impact of the Feed-in Tariff Scheme: Review of Evidence. UK, Department of Energy and Climate Change.

[8] Alizamir S, Véricourt F, Sun P. Efficient Feed-In-Tariff Policies for Renewable Energy Technologies. Operations Research 2016; 64: 52-66.

[9] Zhang R., Ni M., Shen G., Wong J. An analysis on the effectiveness and determinants of the wind power Feed inTariff policy at China's national-level and regional-grid-level. Sustainable Energy Technologies and Assessments 2019; 34: 87-96. 
[10] Li-Fang Chou \& Liang-Feng Lin, (2012). Renewable Energy Feed-in-Tariff System Design and Experience in Taiwan, Low Carbon Policy and Development in Taiwan. Dr. Liang-Feng Lin (Ed.), ISBN: 978-953-51-0156-7, InTech.

[11] Marques D. C., Fuinhas J. A., Macedo D. P. The impact of feed-in and capacity policies on electricity generation from renewable energy sources in Spain. Utility Policy 2019; 56: 159-168.

[12] Couture T. \& Gagnon Y. An analysis of feed-in tariff remuneration models: Implications for renewable energy investment. Energy Policy, 2010; 38: 955-965.

[13] Rickerson W. et al (2008). Exploring Feed-in Tariffs for California. California Energy Commission. Oakland, CA. Sacramento, CA.

[14] Couture T. \& Cory K., (2009). State Clean Energy Policies Analysis (SCEPA) Project: An Analysis of Renewable Energy Feed-in Tariffs in the United States. Golden, CO. National Renewable Energy Laboratory Technical Report No. TP-6A245551 .

[15] Han J., Mol P. J. A., Lu Y., Zhang L. Onshore wind power development in China: Challenges behind a successful story. Energy Policy, 2009; 37: 2941-2951.

[16] Malawi Energy Regulatory Authority, (2012). Malawi feed-in tariff: Renewable energy resource generated electricity in Malawi. Lilongwe, Malawi Energy Regulatory Authority.

[17] Japan International Cooperation Agency, (2013). Kamuzu International Airport to Benefit from the Japanese Government Funded Solar Power Generation Equipment. https://www.jica.go.jp/malawi/english/office/topics/130930.ht $\mathrm{ml}$ [accessed on 11 June 2019].

[18] The Embassy of Japan in Malawi, (2013). Grant Aid Program for Environment and Climate Change Solar Electricity Generation System Handover Ceremony at Kamuzu International Airport. https://www.mw.embjapan.go.jp/Handover\%20ceremony\%20of\%20Solar\%20Elect ricity $\% 20$ Generation $\% 20$ System $\% 20$ at $\% 20$ Kamuzu $\% 20$ Inter national\%20Airport.html [accessed on 11 June 2019].

[19] REN21, (2017). Renewables 2017 Global Status Report. Paris: REN21 Secretariat, http://www.ren21.net/gsr-2017/. [accessed on 18 July 2019].

[20] Ministry of Energy, (2010). Feed-in-tariffs policy for wind, biomass, small-hydro, geothermal, biogas and solar generated electricity. http://kerea.org/wp-content/uploads/2012/12/Feedin-Tariff-Policy-2010.pdf [accessed on 20 June 2019].

[21] COMESA, (2017). Feed-In-Tariffs Guidelines. http://www.comesa.int/wpcontent/uploads/2017/12/FITGuidelines.pdf [accessed on 27 June 2019].

[22] IRENA, (2015). Africa 2030: Roadmap for a Renewable Energy Future. Abu Dhabi, IRENA.

[23] Renschhausen M. Evaluation of feed-in tariff-schemes in African countries. Journal of Energy in Southern Africa, 2013; 24: 56-66.

[24] World Future Council, (2013). Powering Africa through Feedin Tariffs: Advancing renewable energy to meet the continent's electricity needs. A study for the the Heinrich Böll Stiftung and Friends of the Earth England, Wales \& Northern Ireland. Renewable Energy Ventures (K) Ltd. and Meister Consultants Group Inc., Nairobi, Kenya.
[25] Jenner, S., Groba, F., \& Indvik, J. Assessing the strength and effectiveness of renewable electricity feed-in tariffs in the European Union countries. Energy Policy 2013; 52: 385-401.

[26] Rowlands I. The development of renewable electricity policy in the province of Ontario: the influence of ideas and timing. Review of Policy Research, 2007; 24: 185-207.

[27] Moner-Girona et al. Adaptation of Feed-in Tariff for remote mini-grids: Tanzania as an illustrative case. Renewable and Sustainable Energy Reviews 2016; 53: 306-318.

[28] Reserve Bank of Malawi, (2018). Report and Accounts for the year ending 2010-2018. Lilongwe, Malawi. RBM.

[29] Hidayatno A., Dhamayanti R., Destyanto A. R. Model conceptualization for policy analysis in renewable energy development in Indonesia by using system dynamics. International Journal of Smart Grid and Clean Energy, 2019; 8: 54-58.

[30] USAID, (2018). Malawi Power Africa Fact Sheet. https://www.usaid.gov/sites/default/files/documents/1860/Mal awiPACFSDEC20175.508.pdf and https://www.usaid.gov/powerafrica/malawi [accessed on 2 July 2019].

[31] METI. (2016). Management and Engineering Technologies International, Malawi Grid Capacity Study. 364279/PWR/PTD/1/A June 2016 Final Report.

[32] REN21, (2018). Renewables 2018 Global Status Report. Paris: REN21 Secretariat. http://www.ren21.net/wpcontent/uploads/2018/06/17-

8652_GSR2018_FullReport_web_-1.pdf [accessed on 18 July 2019].

[33] REN21, (2019). Renewables 2019 Global Status Report. Paris: REN21 Secretariat, https://www.ren21.net/wpcontent/uploads/2019/05/gsr_2019_full_report_en.pdf [accessed on 11 November 2019].

[34] REN21, (2012). Renewables 2012 Global Status Report. Paris: REN21 Secretariat: http://www.ren21.net/Portals/0/documents/activities/gsr/GSR2 012_low\%20res_FINAL.pdf [accessed on 18 July 2019].

[35] Phiri Grace, (2016, November 10). MCCCI, Government Tussle over Fuel Levies. The Nation Newspaper. https://mwnation.com/mccci-government-tussle-over-fuellevies-2/ [accessed on 25 July 2019].

[36] MG. (2017). Malawi Government, Annual Economic Report 2017. Ministry of Finance, Economic Planning, and Development. Department of Economic Planning and Development. Lilongwe.

[37] Jimu Christopher, (2017, May 11). Businesses to benefit from K30bn Marep 8. The Nation News Paper. $\mathrm{https}: / /$ mwnation.com/businesses-to-benefit-from-k30bnmarep-8/ [accessed on 25 July 2019].

[38] MG. (2016). Malawi Government, Annual Economic Report 2016. Ministry of Finance, Economic Planning, and Development. Lilongwe, Department of Economic Planning and Development.

[39] Mwale Joseph, (2019, August 21). Fuel Crisis Looms. The Nation Newspaper. https://mwnation.com/fuel-crisis-looms/ [accessed on 22 August 2019]. 
[40] MG (2019). Annual Economic Report 2019. Ministry of Finance, Economic Planning and Development, Department of Economic Planning and Development. Lilongwe, Malawi.

[41] ESCOM (2018). Abridged Version of the Base Tariff Application for the Functions of Transmission, Distribution, System Market Operator and the Single Buyer including Bulk Customer and End User Tariffs for the Period 2018/2019 To 2021/2022. https://www.meramalawi.mw/index.php/resourcecenter/press-release/send/18-press-release/80-abridgedversion-of-the-escom-base-tariff-application [accessed on 30 June 2019].
[42] ESCOM (2018). Base Tariff Application for the Functions of Transmission, Distribution, System Market Operator and the Single Buyer Including Bulk Customer and End User Tariffs for the Period 2018/2019 to 2021/2022. Available on https://www.meramalawi.mw/index.php/resourcecenter/press-release/send/18-press-release/82-escom-basetariff-application-main-submission [accessed on 30 June 2019]. 